\title{
PERCERAIAN DAN PERNIKAHAN DINI DI KABUPATEN SEMARANG
}

\author{
Muchamad Coirun Nizar \& Ghofar Shidiq* \\ Universitas Islam Sultan Agung Semarang \\ Email : choirun.nizar@unissula.ac.id
}

\begin{abstract}
The obscurity of the ideal age for a marriage in classical fiqh reference requires the existence of ijtihad among contemporary jurists to determine the ideal age limit for a marriage. The result of the ijtihad is the formulation of a Compilation of Islamic Law which among one of the articles discusses the minimum limit for someone who will hold a marriage (article $15 \mathrm{KHI}$ ) which is 21 years. Including the phenomenon that is rife in Indonesia is the rise of early marriage. Early marriage is defined as a marriage that takes place before maturity is reached both physically and psychologically. In an ideal setting, a marriage continues until death approaches one married couple as exemplified by Rasulullah SAW. But now, divorce occurs in many areas. Divorce occurs because of conflict between husband and wife, or the lack of compatibility between both husband and wife to continue the household. This article is the result of a research linking the occurrence of early marriage and divorce rates in Semarang. The object of this research is the decisions in PA Ambarawa ruling relating to divorce and marriage dispensation requests. In the end, the rise of cases of early marriage in Semarang Regency is due to the rise of free association between teenagers. The results of this study concluded that some divorce decisions in PA Ambarawa in 2014 occurred against the background of early marriage.
\end{abstract}

Kata Kunci : Early Marriage, Divorce, Ambarawa

\begin{abstract}
Abstrak
Ketidakjelasan usia ideal untuk melangsungkan perkawinan dalam referensi fikih klasik, melahirkan suatu ijtihad di kalangan ahli fikih kontemporer Indonesia untuk menentukan batas usia ideal suatu perkawinan. Adapun hasil ijtihad tersebut ditandai dengan lahirnya Kompilasi Hukum Islam yang diantara salah satu pasalnya membahas tentang batas minimal bagi seseorang yang akan melangsungkan perkawinan (pasal $15 \mathrm{KHI}$ ) yakni 21 tahun. Termasuk fenomena yang marak terjadi di Indonesia ialah maraknya pernikahan dini. Pernikahan dini didefinisikan sebagai pernikahan yang dilakukan sebelum tercapai kematangan baik secara fisik maupun psikis. Dalam tatanan ideal, sebuah perkawinan tetap berlangsung hingga kematian menghampiri salah satu pasangan suami istri sebagaimana yang dicontohkan oleh Rasulullah SAW. Namun saat ini, perceraian marak terjadi di berbagai daerah. Perceraian yang terjadi dikarenakan konflik antar suami istri, atau tidak adanya kecocokan antara kedua belah pihak untuk melanjutkan rumah tangga. Artikel ini merupakan hasil penelitian yang mengaitkan antara terjadinya pernikahan dini dan angka perceraian di Kabupaten Semarang. Obyek penelitian yang diteliti adalah putusan PA Ambarawa yang berkaitan dengan perceraian dan permohonan dispensasi nikah. Pada akhirnya, maraknya kasus pernikahan dini di Kabupaten Semarang dikarenakan maraknya pergaulan bebas antara remaja. Hasil penelitian ini menyimpulkan bahwa beberapa putusan perceraian di PA Ambarawa tahun 2014 terjadi dengan latar belakang pernikahan dini.
\end{abstract}

Kata Kunci : Pernikahan Dini, Perceraian, Ambarawa

* Dosen Program Studi Hukum Keluarga (Ahwal Syakhshiyyah) Jurusan Syariah Fakultas Agama Islam Universitas Islam Sultan Agung Semarang. 
ADHKI: Journal of Islamic Family Law

\section{Pendahuluan}

Perkawinan merupakan kebutuhan primer bagi mahluk hidup, khususnya manusia dengan tujuan regenerasi serta yang lainnya. Kehormatan derajat manusia akan akan terjaga jika dia dapat melaksanakan regenerasi melalui jalur resmi bernama pernikahan yang disahkan oleh hukum. Kedamaian dan ketentraman antar anggota keluarga dalam sebuah ikatan pernikahan yang sah juga akan menjaga manusia agar dapat terus hidup menjalankan kefitrahan dan sebagai mahluk yang berkehormatan. ${ }^{1}$ Sebagai makhluk yang dianugrahi nafsu oleh Tuhan, manusia memiliki kecenderungan untuk mencintai dan mengasihi antar satu sama lain. Salah satu contoh dari keinginan untuk mencintai ialah kecenderungan untuk mencintai lawan jenis serta harapan untuk hidup bersama selamanya. Oleh karenanya Islam mensyariatkan pernikahan dengan tujuan dapat menjadi sarana penyaluran kebutuhan berupa kasih sayang terhadap manusia lain dengan tujuan pelestarian sejarah kehidupan manusia di dunia. Maka keluarga merupakan bagian kecil dari masyarakat. ${ }^{2}$

Untuk menjaga kesehatan istri dan keturunan perlu ditetapkan batas usia perkawinan. ${ }^{3}$ Dari segi umur untuk melangsungkan perkawinan, UndangUndang perkawinan Indonesia menganut prinsip bahwa calon suami harus lebih matang jasmani dan rohaninya untuk melangsungkan perkawinan. Agar tujuan perkawinan bisa tercapai, maka setiap orang yang akan melangsunakan perkawinan harus memenuhi syarat-syarat tertentu, yang mana syarat yang dimaksud bukan semata-mata yang bersifat fisik materiil, tetapi hal yang bersifat non fisik yaitu kematangan jiwa mental sesuai tanggung jawab yang nanti akan timbul setelah perkawinan berlangsung, baik tanggung jawab dipihak suami atau istri. Persoalannya sekarang berapa usia perkawinan yang ideal bagi calon suami atau istri, dimana mereka dipandang cukup matang untuk memikul tanggung jawab dalam perkawinan. ${ }^{4}$

Termasuk fenomena yang telah marak terjadi di Indonesia ialah maraknya pernikahan dini. Pernikahan dini atau pernikahan yang dilakukan sebelum tercapai kematangan baik secara fisik maupun psikis. Bahkan tidak jarang, pernikahan yang dilakukan dalam usia dini, sangat rentan akan mengalami perceraian. Pernikahan usia dini menimbulkan permasalahan dan dampak. Di antara permasalahan yang mungkin ditimbulkan antara lain:

a. Pernikahan usia dini ada kecenderungan sangat sulit mewujudkan tujuan perkawinan secara baik.

b. Pernikahan usia dini ada kecenderungan berakhir pada perceraian

\footnotetext{
${ }^{1}$ Ahmad Azhar Basyir, Hukum Pernikahan Islam (Yogyakarta: UII Press, 2004), hlm. 1

${ }^{2}$ Djamal Latief, H. M. SH , Aneka Hukum Peceraian Di Indonesia (Jakarta: Ghalia Indonesia, 1982), hlm. 12

${ }^{3}$ Penjelasan Pasal 7 Undang-Undang No.1 Tahun 1974 Tentang Perkawinan

4 Batas usia minimal perkawinan di Indonesia adalah untuk laki-laki 19 tahun dan perempuan 16 tahun. Lihat Pasal 7 Undang-Undang No.1 Tahun 1974 Tentang Perkawinan dan KHI Pasal 15
} 
c. Pernikahan usia dini sulit mendapat keturunan yang baik dan sehat.

d. Pernikahan mempunyai hubungan dengan masalah kependudukan. Sedangkan dampaknya ialah bahwa batas umur yang rendah bagi seorang wanita untuk kawin, mengakibatkan laju kelahiran lebih tinggi.

Dalam tatanan ideal, demi mewujudkan tujuan perkawinan, sebuah perkawinan diharapkan dapat memiliki orientasi waktu selamanya. ${ }^{5}$ Meski begitu, undang-undang membuka celah dapat diakhirinya sebuah perkawinan melalui perceraian yang dilakukan melalui proses persidangan. ${ }^{6}$ Perkawinan ideal tentunya akan terus berlangsung dalam waktu yang lama dan hanya akan diakhiri melalui perceraian melalui kematian. Namun yang terjadi saat ini, perceraian marak terjadi di berbagai daerah. Perceraian yang terjadi dikarenakan konflik antar suami istri, atau tidak adanya kecocokan antara kedua belah pihak untuk melanjutkan rumah tangga. Dan yang menjadi salah satu indikasi penyebab maraknya perceraian ialah maraknya praktik pernikahan dini. Artikel ini menyajikan informasi hasil penelitian tentang kecenderungan perceraian yang dilatarbelakangi oleh pernikahan dini.

\section{Metode Penelitian}

Jenis Penelitian yang digunakan ialah penelitian kualitatif. Metode kualitatif digunakan untuk mengetahui praktik pernikahan dini di Kabupaten Semarang Tahun 2014 serta pengaruhnya terhadap angka perceraian.

Obyek penelitian ini adalah kasus perceraian di Pengadilan Agama jumlah penelitian dan berdasarkan tujuan penelitian, instrumen yang digunakan serta keterbatasan dana yang ada. Dikarenakan besarnya jumlah obyek penelitian, maka objek diambil ekitar $10 \%-15 \%$ atau $20-25 \%$ atau lebih dari jumlah total obyek penelitian. Artinya dari 1282 kasus perceraian ini diambil sekitar $10 \%-15 \%$ atau $20-25 \%$ atau lebih, tergantung dengan:

a. Kemampuan peneliti dilihat dari segi waktu, tenaga dan dana.

b. Sempit luasnya wilayah pengamatan dari setiap subyek, karena hal ini menyangkut banyak sedikitnya data

c. Besar kecilnya resiko yang ditanggung oleh peneliti. Untuk penelitian yang resikonya besar, tentu saja jika sampel lebih besar maka hasilnya akan lebih baik. ${ }^{7}$

Sedangkan metode analisis yang digunakan bertumpu pada tiga jalur, yaitu: reduksi data, penyajian data dan penarikan kesimpulan. Reduksi data, sebagai bentuk analisis yang mempertajam, mengarahkan, menggolongkan, membuang yang dipandang tidak perlu serta mengorganisasikan data. Adapun cara yang ditempuh: meringkas data, mengkode, menelusuri tema. Penyajian

\footnotetext{
${ }^{5}$ Pasal 1 Undang-Undang No.1 Tahun 1974 Tentang Perkawinan

${ }_{6}^{6}$ Pasal 38 dan 39 Undang-Undang No.1 Tahun 1974 Tentang Perkawinan serta pasal 8 Kompilasi Hukum Islam

7 Suharsimi Arikunto, Prosedur Penelitian Suatu Pendekatan Praktis (Jakarta: Rineka Cipta, 2006), hlm. 270
} 
data, yaitu suatu aktifitas pengelompokan yang tersusun sehingga memberikan kemungkinan adanya kemudahan penarikan kesimpulan dan pengambilan keputusan bertindak. Bentuk-bentuk penyajian data yang dilakukan yaitu: teks naratif dalam bentuk catatan lapangan, pembuatan matrik, grafik, jaringan dan bagan-bagan. Penarikan kesimpulan, yaitu aktifitas yang bermula dari awal penelitian melalui sebuah pendekatan spesifik tentang pengartian dan pemaknaan terhadap benda-benda, catatan-catatan keteraturan pola, konfigurasi yang mungkin terjadi, alur sebab akibat maupun proposisi.

\section{Pernikahan Dini Pelbagai Perspektif}

Praktik perkawinan di Indonesia diatur oleh undang-undang khusus yakni UU No. 1 Tahun 1974 tentang perkawinan. Dalam UU tersebut, perkawinan mempunyai hubungan erat dengan masalah kependudukan. Dengan adanya pembatasan umur perkawinan baik bagi wanita maupun pria diharapkan lajunya kelahiran dapat ditekan semaksimal mungkin. Di sini UU perkawinan membatasi umur untuk melaksanakan perkawinan yaitu 19 tahun bagi pria dan 16 tahun bagi wanita, penyimpangan dari batas umur minimal perkawinan ini harus mendapat dispensasi pengadilan lebih dahulu, setelah itu perkawinan baru dapat dilaksanakan (Abdul Manan, 2006: 11). ${ }^{8}$

Berkaitan dengan adanya batasan usia minimal dalam perkawinan terdapat perbedaan pendapat di antara ahli fikih, yang mana para ahli fikih biasanya mendasarkan pada kematangan seseorang yang dapat dilihat dari kematangan akal (rusyd). Itu merupakan suatu pertanda bahwa seseorang untuk mampu melaksanakan kecakapan sempurna termasuk di dalamnya kecakapan melangsungkan perkawinan. Selain itu juga para ahli fiqh menilai bahwa 'akil baligh dengan ciri-ciri apabila seorang anak laki-laki telah mengalami mimpi basah, sedangkan utuk perempuan telah mengalami haid. ${ }^{9}$

Ketidakjelasan usia ideal untuk melangsungkan perkawinan dalam referensi fikih klasik, melahirkan suatu ijtihad di kalangan ahli fikih kontemporer Indonesia untuk menentukan batas usia ideal suatu perkawinan. Adapun hasil ijtihad tersebut ditandai dengan lahirnya Kompilasi Hukum Islam yang diantara salah satu pasalnya membahas tentang batas minimal bagi seseorang yang akan melangsungkan perkawinan (pasal $15 \mathrm{KHI}$ ) selanjutnya mengenai pengertian di bawah usia 21 tahun (di bawah umur) dalam KHI disebutkan. hlm. 11

8 Abdul Manan, Aneka Masalah Hukum Perdata Islam di Indonesia (Jakarta: Kencana, 2006),

${ }^{9}$ Pendapat Ulama Madzhab tentang batasan dewasa yang berkaitan dengan usia adalah sebagai berikut:

1. Menurut madzhab Hanafi, Syafii dan Hambali adalah 15 tahun

2. Menurut madzhab Maliki 12 tahun.

Sedangkan tanda baligh yang berkaitan dengan kejadian fisik, ulama 4 madzhab sepakat dalam hal keluarnya mani (sperma) dan haid. Baca: al Jazairi, Al Figh ala Madzahib al Arba'ah (Maktabah Syamilah Ishdar 3.61) 
“Untuk kemaslahatan keluarga dan rumah tangga, perkawinan hanya boleh dilakukan calon mempelai yang telah mencapai umur yang telah ditetapkan dalam pasal 7 (1) UU No. 1 Th 1974 yakni calon suami sekurang-kurangnya berumur 19 tahun dan calon istri berumur 16 tahun" .

"Bagi calon mempelai yang belum mencapai umur 21 tahun harus mendapat izin sebagaimana yang diatur dalam pasal 6 ayat (2), (3), (4), dan (5) UU No 1 Th 1974."10

Apabila dilihat dari isi pasal 15 ayat $2 \mathrm{KHI}$ itu menunjukkan usia ideal perkawinan adalah 21 tahun, sedangkan pasal 15 ayat 1 menunjukkan ketentuan minimal usia suatu perkawinan sehingga dipandang perlu suatu izin dari orang tua. Sedangkan dalam pasal 7 ayat 1 UU perkawinan menyebutkan bahwa perkawinan hanya diizinkan jika pihak pria sudah mencapai umur 19 tahun dan pihak wanita mencapai umur 16 tahun.

Dalam penjelasan atas UU RI No 1 Tahun 1974 pasal 7(1) menegaskan bahwa untuk menjaga kesehatan istri dan keturunan perlu ditetapkan batas usia perkawinan. Dari segi umur untuk melangsungkan perkawinan, UndangUndang perkawinan Indonesia menganut prinsip bahwa calon suami harus lebih matang jasmani dan rohaninya untuk melangsungkan perkawinan. Agar tujuan perkawinan bisa tercapai, maka setiap orang yang akan melangsunakan perkawinan harus memenuhi syarat-syarat tertentu, yang mana syarat yang dimaksud bukan semata-mata yang bersifat fisik materiil, tetapi hal yang bersifat non fisik yaitu kematangan jiwa mental sesuai tanggung jawab yang nanti akan timbul setelah perkawinan berlangsung, baik tanggung jawab dipihak suami atau istri. Persoalannya sekarang berapa usia perkawinan yang ideal bagi calon suami atau istri, dimana mereka dipandang cukup matang untuk memikul tanggung jawab dalam perkawinan.

Jika dilihat dari perspektif hukum, batasan usia menikah ideal ialah 21 tahun sebagaimana disebutkan dalam KHI pasal 15 ayat (2) jo Undang-Undang No.1 tahun 1974 tentang perkawinan pasal 6 ayat (2). Meski pada hakikatnya, usia 19 bagi laki-laki dan usia 16 bagi perempuan dizinkan juga untuk melaksanakan perkawinan, namun dengan catatan harus atas izin orang tua. Karena dalam Undang-Undang No. 35 tahun 2014 tentang perlindungan anak, usia di bawah 18 tahun masih digolongkan sebagai anak.

Dalam perpektif kesehatan, BKKBN Indonesia merekomendasikan usia pernikahan ideal adalah 21-25 tahun. ${ }^{11}$ Pertimbangan usia ideal minimal perikahan ialah 21-25 tahun ialah merujuk pada usia kematangan seseorang jika dipandang dari aspek biologis dan pasikologis. Eddy Fadlyana menuliskan bahwa pernikahan dini yang menyebabkan kehamilan dini, yakni sebelum usia 17 tahun dapat meningkatkan komplikasi medis baik pada calon anak maupun ibu. Dampak resiko kehamilan yang paling parah berupa kematian ternyata juga

\footnotetext{
${ }^{10}$ KHI Pasal 15

${ }^{11}$ https://www.bkkbn.go.id/
} 
semakin besar kemungkinannya dialami oleh perempuan yang hamil di usia muda. ${ }^{12}$

Permasalahan perbedaan penentuan minimal usia nikah merupakan hal yang wajar dalam perpektif hukum Islam. Penetapannya tentu tidak mudah dan diperlukan usaha yang keras dalam penelaahannya baik dengan menggunakan landasan dalil yang ada maupun dengan metodologi hukum Islam. Senada dengan hal itu, Ahmad Rofiq menyatakan bahwa masalah penentuan umur dalam undang-undang perkawinan maupun dalam kompilasi, memang bersifat ijtihâdiah, sebagai usaha pembaharuan pemikiran fiqh yang lalu, meskipun demikian, apabila dilacak referensi syar'inya mempunyai landasan kuat. ${ }^{13}$

Sebenarnya, yang terjadi dalam kasus pernikahan dini tidak hanya halhal yang bersifat negatif saja. Secara psikologis, menurut Fauzil Adzim, pernikahan dini dapat meningkatkan stamina dan kesehatan disebabkan kebutuhan fisik yang terpenuhi. ${ }^{14}$ Selain itu, Casmini dalam penelitiannya menyebutkan bahwa meski secara fisik dan psikis, pernikahan dini dianggap negatif karena minimnya kematangan dalam keduanya, namun setidaknya pernikahan dini memiliki sisi positif berupa stabilitas kontrol sahwat yang lebih terjamin. ${ }^{15}$

\section{Pernikahan dini di Kabupaten Semarang}

Pernikahan dini yang dimaksud dalam penelitian ini ialah pernikahan dini yang dicatatkan dan terlebih dahulu dimintakan permohonan dispensasi nikah di Pengadilan Agama. Oleh karena itu, dalam rangka mengetahui praktik pernikahan dini yang terjadi di Kabupaten Semarang, penulis menganalisa putusan-putusan PA berkenaan dengan permohonan dispensasi nikah. Hasil penelusuran penulis, bahwasanya selama tahun 2014, telah diajukan permohonan dispensasi nikah sebanyak 21 kasus yang semuanya dikabulkan oleh PA Ambarawa.

Dari 21 permohonan dispensasi nikah, semuanya diajukan oleh pihak orang tua kandung dengan tujuan memohon agar PA Ambarawa mengabulkan permohonan dispensasi nikah untuk anak kandung mereka yang telah lama menjalin hubungan dengan kekasihnya. Usia anak kandung pemohon yang akan dimintakan dispensasi nikahnya berkisar antara 14 hingga 18 tahun. Jenis kelamin anak pemohon juga ada yang laki-laki dan perempuan. Dari 21 permohonan dispensasi nikah, 7 di antara diajukan oleh orang tua dari pihak perempuan. Sedangkan 14 permohonan diajukan oleh pihak orang tua laki-laki.

${ }^{12}$ Fadlyana, E., “Pernikahan Usia Dini dan Permasalahannya”, Jurnal Sari Pediatri, Vol.11, No.2, 2009, hlm. 136-140

${ }^{13}$ Ahmad Rofiq, Hukum Islam di Indonesia (Jakarta: PT.Raja Grafindo Persada, 1977), hlm. 77

${ }^{14}$ Fauzil Adhim, Indahnya Pernikahan Dini (Jakarta: Gema Insani Press, 2002), hlm. 4

${ }^{15}$ Casmini, "Pernikahan Dini (Perspektif Psikologi dan Agama)", Aplikasia, Jurnal Aplikasi Ilmu-Ilmu Agama, Vol. 3, No.1, Juni 2002, hlm. 45-57 
Jika dilihat dari faktor usia, dari 21 permohonan dispensasi nikah yang diajukan ke PA Ambarawa, usia anak laki-laki para pemohon (calon mempelai pria) ada dalam kisaran 15 sampai 18 tahun. Sedangkan anak perempuan para pemohon (calon mempelai wanita) berkisar antara 14 hingga 15 tahun. Jika dirinci lebih detail, jumlah anak laki-laki para pemohon (calon mempelai pria) yang berusia 15 tahun saat diajukan permohonan dispensasi nikahnya berjumlah 2 orang. Sedangkan yang berusia 16 tahun sebanyak 4 orang. Yang berusia 17 tahun berjumlah 2 orang. Dan yang berusia 18 tahun berjumlah 5 orang. Sedangkan jumlah anak perempuan para pemohon (calon mempelai wanita) yang berusia 14 tahun berjumlah 3 orang. Dan yang berusia 15 tahun berjumlah 4 orang.

Hasil penelusuran penulis, bahwa seluruh permohonan dispensasi nikah di PA Ambarawa dikabulkan oleh PA Ambarawa. Pertimbangan yang digunakan hakim dalam mengabulkan permohonan dispensasi nikah tersebut juga sama, yakni karena adanya latar belakang hubungan yang sangat erat antara anak pemohon dengan kekasihnya. Dari 21 permohonan dispensasi nikah, semuanya dilatar belakangi adanya hubungan yang sangat erat antara anak pemohon dengan kekasihnya. Bahkan 3 di antara 21 permohonan tersebut dilatar belakangi oleh adanya hubungan pertunangan yang telah lama terjalin. Ada yang telah bertunangan 2 tahun. Ada juga yang telah bertunangan 3 tahun. Namun ada juga yang baru bertunangan 3 bulan. Selain yang telah bertunangan, hubungan yang terjalin antara pasangan yang dimohonkan dispensasi nikahnya, telah terjalin dengan usia hubungan bermacam-macam. Yang telah berhubungan erat selama 1, 6 dan 8 adalah 1 pasangan. 2 pasangan telah berhubungan selama 10 bulan. Yang telah berhubungan erat selama 1 tahun ada 7 pasangan. Sedangkan 5 pasangan telah berhubungan erat selama 2 tahun. Dan 1 pasangan lagi telah berhubungan selama 2 tahun lebih 6 bulan.

Dari 21 permohonan dispensasi nikah karena pasangan anak pemohon dan kekasihnya telah berhubungan dalam rentang waktu yang bermacammacam tersebut, sebagian di antaranya masih dapat menjaga diri untuk tidak berhubungan intim layaknya suami istri. Namun sebagian besar dari jumlah pasangan dispensasi nikah telah melakukan hubungan seksual layaknya suami istri, bahkan ada yang sampai hamil. Rinciannya, dari 21 pasangan dispensasi nikah, 5 pasangan ternyata masih mampu menjaga dirinya dari perbuatan hubungan seksual. Sedangkan sisanya, telah melakukan hubungan seksual.

Dari 14 pasangan yang telah melakukan hubungan seksual telah mengalami kehamilan di luar pernikahan. Artinya, baik anak pemohon maupun calon istri anak pemohon telah hamil pada saat diajukannya permohonan dispensasi nikah. Usia kehamilannya beraneka ragam dari mulai 3 sampai 7 bulan. Jika dirinci lagi, dari 15 pasangan yang mengalami kehamilan di luar nikah, 2 di antaranya hamil 3 bulan. 1 di antaranya hamil 4 bulan. 5 orang dalam keadaan usia kandungan 5 bulan. 4 orang dalam keadaan usia kandungan 6 
bulan dan 1 di antaranya hamil 7 bulan. Sedangkan 2 pasangan dari 16 yang telah melakukan hubungan seksual di luar nikah, belum mengalami kehamilan.

\section{Perceraian dan Pernikahan Dini di Kabupaten Semarang}

Dalam penelusuran penulis, jumlah perkara perceraian yang diputus tahun 2014 di PA Ambarawa ialah sebanyak 1282 putusan. Penulis mengambil sampel secara acak sebanyak 109 kasus perceraian di PA Ambarawa yang diputus pada tahun 2014. Di antara putusan yang dijadikan sample, ditentukan perceraian yang dilatarbelakangi pernikahan dini baik yang dirumuskan oleh Undang-Undang maupun yang dicanangkan oleh BKKBN.

Dari seluruh sampel yang diambil, terdapat 10 kasus perceraian yang diputus tanpa dilatarbelakangi pernikahan dini. Artinya, 10 pasang suami istri yang bercerai di tahun 2014 di PA Ambarawa adalah pasangan yang menikah sesuai dengan kriteria ideal BKKBN. Sedangkan 16 kasus perceraian yang diputus dengan dilatarbelakangi pernikahan dini menurut UU no. 1 Tahun 1974 tentang perkawinan. Artinya, 16 pasang suami istri yang bercerai di tahun 2014 di PA Ambarawa adalah pasangan yang menikah di bawah usia ideal yang diperbolehkan oleh UU tersebut. Adapun perceraian yang dilatarbelakangi pernikahan dini di bawah usia ideal 21 tahun versi BKKBN terdapat 99 kasus. Artinya, 99 pasang suami istri yang bercerai di tahun 2014 di PA Ambarawa adalah pasangan yang menikah di bawah usia ideal 21 tahun. Sedangkan jika dirunut menggunakan UU. No.35 Tahun 2014 tentang Perlindungan Anak, terdapat 42 kasus perceraian yang dilatarbelakangi pernikahan anak. Lebih jelasnya dapat dilihat dari tabel sebagai berikut:

\section{Grafik 1. Klasifikasi Putusan Cerai PA Ambarawa 2014}

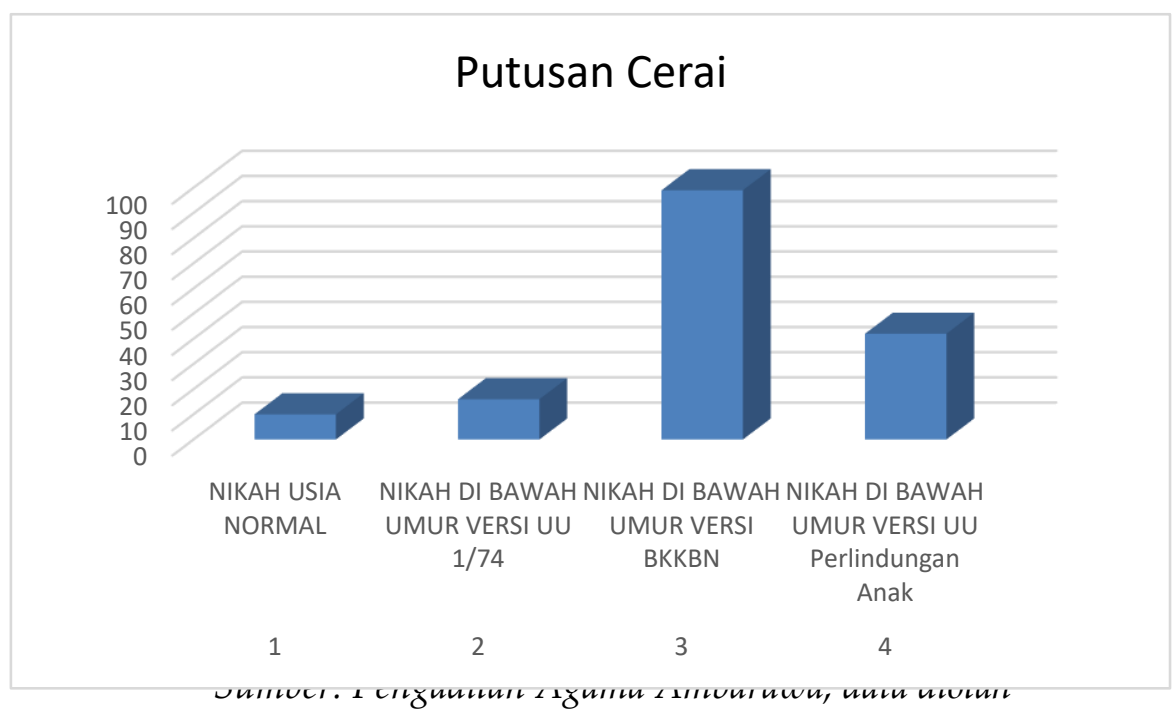

132 Perceraian dan Pernikahan Dini ... 
Sebagai catatan, jenis perkara yang diteliti meliputi perceraian baik cerai talak (CT) maupun cerai gugat (CG). Sebagaimana telah dijelaskan, berikut penulis lampirkan hasil olah data putusan perceraian PA Ambarawa tahun 2014 yang dilatarbelakangi pernikahan dengan usia normal, sesuai aturan.

Tabel 1:

Putusan Cerai PA Ambarawa 2014 Usia Nikah Normal

\begin{tabular}{|c|c|c|c|c|c|c|c|c|c|}
\hline \multirow{2}{*}{ No } & \multirow{2}{*}{ Nomer Perkara } & \multirow{2}{*}{$\begin{array}{c}\text { Jenis } \\
\text { Perkara }\end{array}$} & \multirow{2}{*}{$\begin{array}{c}\text { Tahun } \\
\text { Menikah }\end{array}$} & \multirow{2}{*}{$\begin{array}{c}\text { Tahun } \\
\text { Cerai }\end{array}$} & \multirow{2}{*}{$\begin{array}{c}\text { Durasi } \\
\text { Sejak } \\
\text { Menikah }\end{array}$} & \multicolumn{2}{|c|}{ Usia Saat Cerai } & \multicolumn{2}{|c|}{ Usia Saat Kawin } \\
\hline & & & & & & SUAMI & ISTRI & SUAMI & ISTRI \\
\hline 1 & 0405/Pdt.G/2014/PA.Amb & CG & 2004 & 2014 & 10 & 33 & 32 & 23 & 22 \\
\hline 2 & 0639/Pdt.G/2014/PA.Amb & CG & 1995 & 2014 & 19 & 44 & 40 & 25 & 21 \\
\hline 3 & 0645/Pdt.G/2014/PA.Amb & CG & 2002 & 2014 & 12 & 39 & 36 & 27 & 24 \\
\hline 4 & 0696/Pdt.G/2014/PA.Amb & CG & 1999 & 2014 & 15 & 38 & 36 & 23 & 21 \\
\hline 5 & 0833/Pdt.G/2014/PA.Amb & CG & 2012 & 2014 & 2 & 30 & 23 & 28 & 21 \\
\hline 6 & 0878/Pdt.G/2014/PA.Amb & CG & 1999 & 2014 & 15 & 41 & 36 & 26 & 21 \\
\hline 7 & 0951/Pdt.G/2014/PA.Amb & $\mathrm{CT}$ & 2002 & 2014 & 12 & 37 & 33 & 25 & 21 \\
\hline 8 & 0976/Pdt.G/2014/PA.Amb & CG & 2013 & 2014 & 1 & 28 & 22 & 27 & 21 \\
\hline 9 & 0987/Pdt.G/2014/PA.Amb & $\mathrm{CT}$ & 2001 & 2014 & 13 & 34 & 40 & 21 & 27 \\
\hline 10 & 1058/Pdt.G/2013/PA.Amb & CG & 2005 & 2014 & 9 & 31 & 31 & 22 & 22 \\
\hline
\end{tabular}

Sumber: Pengadilan Agama Ambarawa, data diolah

Durasi sejak menikah yang dimaksud ialah waktu sejak pernikahan terjadi antara keduanya. Bukan keberlangsungan pernikahan dalam suasana harmonis. Sebab beberapa kondisi rumah tangga yang diteliti penulis beragam.

Sedangkan perceraian yang dilatarbelakangi dengan latar belakang pernikahan dini menurut UU no. 1 Tahun 1974 tentang perkawinan sebanyak 16 kasus. Sebagai contoh, kasus perceraian yang diputus dengan nomor putusan 0277/Pdt.G/2014/PA.Amb. Perceraian tersebut dilatarbelakangi oleh pernikahan di bawah umur yakni pihak perempuan ketika menikah berusia 14 tahun sedangkan pihak laki-laki berusia 20 tahun. Selanjutnya putusan dengan nomor: 0303/Pdt.G/2014/PA.Amb. yang dilatar belakangi pernikahan pasangan berusia 20 tahun dan 21 tahun. Lebih lengkapnya, akan penulis paparkan hasil pengolahan data putusan PA Ambarawa tahun 2014 yang dijadikan sampel dalam penelitian ini.

Tabel 2

Putusan Cerai PA Ambarawa 2014 Usia Nikah Dini

\begin{tabular}{|c|c|c|c|c|c|c|c|c|c|}
\hline \multirow{2}{*}{ No. } & \multirow{2}{*}{ Nomer Perkara } & \multirow{2}{*}{$\begin{array}{c}\text { Jenis } \\
\text { Perkara }\end{array}$} & \multirow{2}{*}{$\begin{array}{c}\text { Tahun } \\
\text { Menikah }\end{array}$} & \multirow{2}{*}{$\begin{array}{l}\text { TAHUN } \\
\text { Cerai }\end{array}$} & \multirow{2}{*}{$\begin{array}{c}\text { Durasi } \\
\text { Sejak } \\
\text { Menikah }\end{array}$} & \multicolumn{2}{|c|}{$\begin{array}{l}\text { USIA SAAT } \\
\text { CERAI }\end{array}$} & \multicolumn{2}{|c|}{$\begin{array}{l}\text { USIA SAAT } \\
\text { KAWIN }\end{array}$} \\
\hline & & & & & & SUAMI & ISTRI & SUAMI & ISTRI \\
\hline 1 & 0277/Pdt.G/2014/PA.Amb & CG & 2004 & 2014 & 10 & 30 & 25 & 20 & 15 \\
\hline 2 & 0494/Pdt.G/2014/PA.Amb & CG & 1979 & 2014 & 35 & 49 & 43 & 14 & 8 \\
\hline 3 & 0597/Pdt.G/2014/PA.Amb & CG & 2012 & 2014 & 2 & 20 & 18 & 18 & 16 \\
\hline 4 & 0641/Pdt.G/2014/PA.Amb & $\mathrm{CT}$ & 1997 & 2014 & 17 & 38 & 28 & 21 & 11 \\
\hline 5 & 0662/Pdt.G/2014/PA.Amb & CG & 2014 & 2014 & 0 & 17 & 18 & 17 & 18 \\
\hline
\end{tabular}


ADHKI: Journal of Islamic Family Law

\begin{tabular}{|l|l|l|l|l|l|l|l|l|l|}
\hline 6 & $0663 /$ Pdt.G/2014/PA.Amb & CG & 2003 & 2014 & 11 & 28 & 28 & 17 & 17 \\
\hline 7 & $0668 /$ Pdt.G/2012/PA.Amb & CG & 1991 & 2014 & 23 & 42 & 34 & 19 & 11 \\
\hline 8 & $0675 /$ Pdt.G/2014/PA.Amb & CG & 2009 & 2014 & 5 & 21 & 21 & 16 & 16 \\
\hline 9 & $0829 /$ Pdt.G/2014/PA.Amb & CG & 1974 & 2014 & 40 & 58 & 57 & 18 & 17 \\
\hline 10 & $0897 /$ Pdt.G/2013/PA.Amb & CG & 1981 & 2014 & 33 & 52 & 48 & 19 & 15 \\
\hline 11 & $0952 /$ Pdt.G/2014/PA.Amb & CG & 1998 & 2014 & 16 & 35 & 30 & 19 & 14 \\
\hline 12 & $1011 /$ Pdt.G/2014/PA.Amb & CG & 2008 & 2014 & 6 & 21 & 23 & 15 & 17 \\
\hline 13 & $1020 /$ Pdt.G/2013/PA.Amb & CG & 1994 & 2014 & 20 & 47 & 34 & 27 & 14 \\
\hline 14 & $1041 /$ Pdt.G/2013/PA.Amb & CG & 2012 & 2014 & 2 & 20 & 18 & 18 & 16 \\
\hline 15 & $1093 /$ Pdt.G/2013/PA.Amb & CT & 1995 & 2014 & 19 & 38 & 34 & 19 & 15 \\
\hline 16 & $1126 /$ Pdt.G/2013/PA.Amb & CT & 2000 & 2014 & 14 & 34 & 27 & 20 & 13 \\
\hline
\end{tabular}

Sumber: Pengadilan Agama Ambarawa, data diolah

Jika diteliti lagi, terdapat 3 kasus perceraian yang pernikahannya diselenggarakan sebelum ditetapkannya Inpres KHI Tahun 1991, yakni putusan cerai 0494/Pdt.G/2014/PA.Amb., putusan No. 0829/Pdt.G/2014/PA.Amb. dan putusan no. 0897/Pdt.G/2013/PA.Amb. Artinya, pernikahan 3 pasangan tersebut telah menikah sebelum ditetapkannya KHI dengan Inpres No. 1 tahun 1991.

Jika pernikahan dini mengacu pada usia standar ideal yang ditetapkan BKKBN yakni 21 tahun, maka jumlah kasus perceraian di PA Ambarawa tahun 2014 yang dilatarbelakangi pernikahan dini sebanyak 99 kasus. 16 di antaranya di bawah umur yang ditetapkan UU No.1 Tahun 1974. Sisanya yakni sebanyak 83 kasus dilatarbelakangi pernikahan di bawah usia 21 tahun. Dari 99 kasus perceraian di PA Ambarawa tahun 2014 yang dilatarbelakangi pernikahan dini (di bawah 21 tahun), sebanyak 60 pernikahan dengan salah satu pasangan yang masih di bawah umur. Sedangkan sisanya 39 pasangan, masing-masing dari keduanya menikah di bawah umur. Lebih jelasnya penulis ungkapkan dalam tabel berikut :

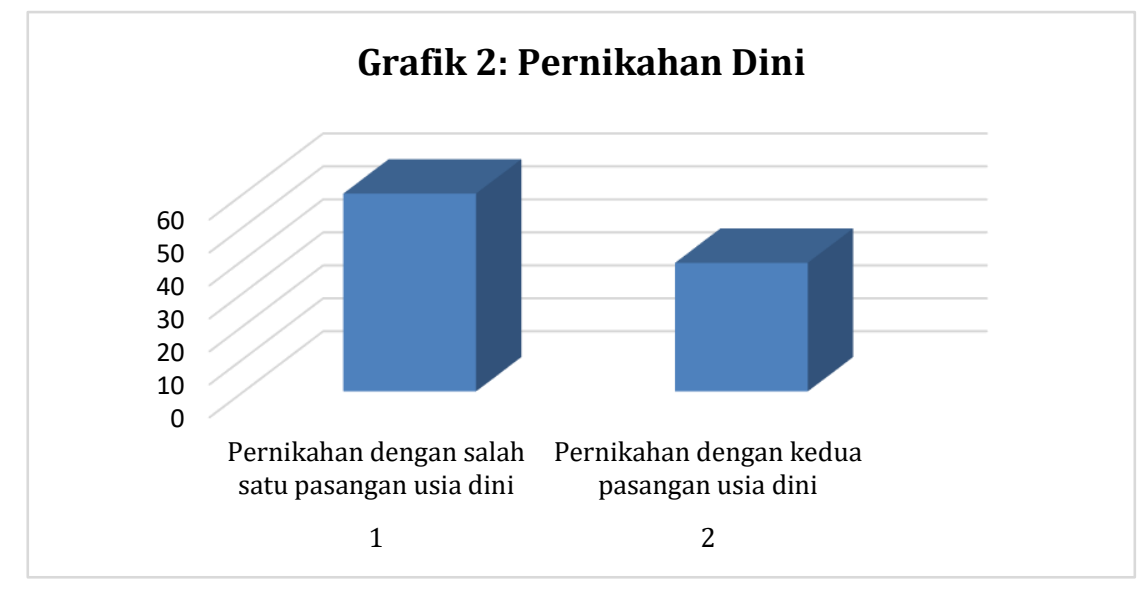

Sumber : PA Ambarawa, data diolah 
Jika diolah dalam bentuk prosentase, pada akhirnya sekitar 9,2\% kasus perceraian yang diputus tanpa dilatarbelakangi pernikahan dini atau pasangan yang menikah sesuai dengan kriteria ideal BKKBN maupun UU. Sedangkan 14,7\% kasus perceraian yang diputus di PA Ambarawa tahun 2014 dengan dilatarbelakangi pernikahan dini menurut UU no. 1 Tahun 1974 tentang perkawinan. Dan sebanyak 90,8\% (termasuk 14,7\% kriteria sebelumnya) kasus perceraian yang diputus di PA Ambarawa tahun 2014 yang dilatarbelakangi pernikahan dini di bawah usia ideal 21 tahun versi BKKBN. Sedangkan 38,5\% putusan perceraian di PA Ambarawa tahun 2014 yang dilatarbelakangi dengan pernikahan anak.

\section{Kesimpulan}

Pelaksanaan Pernikahan dini ini terjadi karena ada beberapa sebab yang sangat menghawatirkan dan mendesak yaitu: pertama: Pernikahan usia dini mendesak untuk laksanakan karena kedua pasangan telah berhubungan cinta sejak lama yaitu satu bulan; dua bulan; dan seterusnya, dan hubungan keduanya sudah sedemikian eratnya, sehingga sangat khawatir akan terjadi perbuatan yang dilarang oleh ketentuan hukum Islam apabila tidak segera dinikahkan, dan bahkan ada yang sudah hamil beberapa minggu dan bulan sebelum pertunagan; kedua: Karena keduanya telah bertunangan sejak kurang lebih berbulan-bulan dan beberapa tahun yang lalu dan hubungan mereka telah sedemikian eratnya, bahkan hubungan mereka sangat akrab dan ada yang sudah tinggal serumah, bahkan sudah berhubungan intim sebagaimana layaknya pasangan suami isteri, walupun ada yang sampai belum hamil, namun kebanyakan dari mereka ada yang telah hamil beberapa minggu, dan beberapa bulan.

Perceraian yang diputus tahun 2014 di PA Ambarawa sebanyak 1282 putusan. Beberapa di antaranya dilatarbelakangi dengan terjadinya pernikahan dini baik salah satu pihak maupun kedua belah pihak. Berdasarkan penelitian yang telah dilakukan, hanya sekitar 9,2\% kasus perceraian yang diputus tanpa dilatarbelakangi pernikahan dini atau pasangan yang menikah sesuai dengan kriteria ideal BKKBN maupun UU. Sedangkan 14,7\% kasus perceraian yang diputus di PA Ambarawa tahun 2014 dengan dilatarbelakangi pernikahan dini menurut UU no. 1 Tahun 1974 tentang perkawinan. Dan sebanyak 90,8\% (termasuk 14,7\% kriteria sebelumnya) kasus perceraian yang diputus di PA Ambarawa tahun 2014 yang dilatarbelakangi pernikahan dini di bawah usia ideal 21 tahun versi BKKBN. Sedangkan 38,5\% putusan perceraian di PA Ambarawa tahun 2014 yang dilatarbelakangi dengan pernikahan anak. 
ADHKI: Journal of Islamic Family Law

\section{Daftar Pustaka}

Abdul Manan, Aneka Masalah Hukum Perdata Islam di Indonesia, Jakarta: Kencana, 2006

Adhim, Fauzil, Indahnya Pernikahan Dini, Jakarta: Gema Insani Press, 2002

al Jazairi, Al Fiqh ala Madzahib al Arba'ah (Maktabah Syamilah Ishdar 3.61)

Arikunto, Suharsimi, Prosedur Penelitian Suatu Pendekatan Praktis Jakarta: Rineka Cipta, 2006

Basyir, Ahmad Azhar, Hukum Pernikahan Islam, Yogyakarta: UII Press, 2004

Casmini, "Pernikahan Dini (Perspektif Psikologi dan Agama)", Aplikasia: Jurnal Aplikasi Ilmu-Ilmu Agama, Vol. 3, No.1, Juni 2002

Djamal Latief, H. M SH, Aneka Hukum Perceraian Di Indonesia, Jakarta: Ghalia Indonesia, 1982

Fadlyana, E., "Pernikahan Usia Dini dan Permasalahannya", Jurnal Sari Pediatri, Vol.11, No.2, 2009

Rahmat Hakim, Hukum Pernikahan Islam, Bandung: CV Pustaka Setia, 2000

Rofiq, Ahmad, Hukum Islam di Indonesia, Jakarta: PT.Raja Grafindo Persada, 1977

Kompilasi Hukum Islam

Undang-Undang No.1 Tahun 1974 Tentang Perkawinan

https://www.bkkbn.go.id/

Undang-Undang No. 35 tahun 2014 Tentang Perlindungan Anak 